\title{
ANALYSIS OF FINANCIAL RATIO THAT AFFECTING TOTAL FINANCING OF BANK UMUM SYARIAH IN INDONESIA
}

\author{
Zerlinda Tharifah Ulfa1, Purwanto ${ }^{2}$ \\ 1,2Faculty of Business, President University, Bekasi, Indonesia \\ $\triangle$ 2purwanto@president.ac.id
}

\begin{abstract}
This study aimed to analyze the factors that influence the Total Financing of Bank Umum Syariah (BUS) in Indonesia. Islamic banking system in Indonesia was developed within the framework of the dual banking system to give alternatives for more complete banking services to the people of Indonesia. Islamic banking in Indonesia has grown rapidly every year, but it can not be denied the role of Islamic banking in the economy is still relatively small compared with conventional banking. The amount of total financing is only about 5,56\% of the banking total credit. It can be seen also in the proportion of assets Islamic banking to national banking assets that only $4.8 \%$ and $18.75 \%$ of the total national banking accounts. The research data is taken from the financial reports of 10 of Islamic banks in Indonesia. The method used is a quantitative method and multiple regression analysis, proceed using SPSS to test normality, multicollinearity, heteroscedasticity and autocorrelation. The result of this research showed that the Capital Adequacy ratio(CAR), NonPerforming Financing (NPF), and Operating Expense Operating Income ratio (OEOI) had a significant effect on total financing. Meanwhile, Return on Asset (ROA) and Financing to Deposit Ratio (FDR) had no significant effect on the total financing of Bank Umum Syariah. Adjusted R Square value is 0.239 or $23,9 \%$. This value shows that the percentage of the contribution of independent variables on total financing is $23.9 \%$. The remaining percentages are due to other variables excluded in this model.
\end{abstract}

Keywords: $\quad$ total financing, CAR, NPF, OEOI, ROA, FDR

\section{INTRODUCTION}

Islamic banking system in Indonesia was developed within the framework of the dual banking system to give alternatives for more complete banking services to the people of Indonesia. Islamic banking and conventional banking develop synergic to mobilize public funds and improving funding for the national economy. Islamic banking operates based on the principle of mutual benefit for the community and the banks and highlights the aspect of fairness in transaction and ethical investment, promoting the values of solidarity and partnership in production, and avoiding speculative activity in financial transactions. The legal basis for Islamic banking is the Law No. 21 of 2008 on Islamic Banking.

As has been stated also in the Law No.10 of 1998 on banking, it can be concluded that the bank can act as a financial intermediary to conduct fundraising from the public that has the surplus funds in form of deposits. Then the bank will pay interest to its customers and channel funds to communities that lack of funds in the form of credit. The need for financing which relieves society of its course provides opportunities to banks as providers of funds. Following the main principles of a bank as the collector and distributor of funds. Funds that have been compiled from various sources, should 
be allocated to productive ventures that will benefit the bank (Triandaru and Santoso, 2006).

Islamic banks have two basic principles which are the sharing of profit and loss and, significantly, the prohibition of the collection and payment of interest by lenders and investors. Collecting interest or "Riba" is not permitted under Islamic law. Islamic banks in Indonesia are divided into three types. The first one is the Islamic commercial bank or Bank Umum Syariah (BUS), which is a pledged bank that operates throughout the country. The second is Islamic business unit or Unit Usaha Syariah (UUS), which is a special division established by conventional bank which can also be operated everywhere in the country, and the third is Islamic rural bank or Bank Pembiayaan Rakyat Syariah (BPRS), which only operates in a specific rural and urban area. Another difference among these three banks is the capital requirements to establish a bank set by Bank Indonesia. Based on Bank Indonesia Regulation No.11/3/PBI/2009, the Bus working capital is set out for 1 trillion rupiahs, and 100 billion rupiahs for UUS. As of August 2016, Indonesia has 12 BUS, 34 UUS, and 164 BPRS (Islamic Banking Statistic of Bank Indonesia, 2016). Based on Islamic banking statistics of Bank Indonesia (2016), the Total Financing provided by Islamic banks (BUS and UUS).

Islamic banking in Indonesia has grown rapidly, it can be seen on the table above the growth in the number of Islamic banking offices from 2010 until 2015 increased significantly as many as 920 Islamic bank office (in 2010 the total office is 1,215 increased to 2,135 Office in 2015) Which consists of 12 Islamic commercial bank. Bank Indonesia recorded that within 17 years of the Islamic banking has grown by 27 times. Islamic banking assets in 2000 is 1.79 trillion to IDR 49.6 trillion at the end of 2008, even has reached 297.93 trillion rupiah in the second quarter of 2016. When combined with the assets of Syariah Rural Bank (BPRS), the Islamic banking assets reached 306.02 trillion rupiah. Islamic banking market share has reached $4.81 \%$ by August 2016, with the number of Islamic banking accounts reached 15 million accounts, equivalent to $18.75 \%$ of the total national banking accounts as well as the number of branch networks which reaches 2157.

Islamic banking has a role as an intermediary institution. This role is demonstrated by the ability of Islamic banking to channel Third Party Fund (TPF) through financing. Development of total financing and third party fund (TPF) of Bank Umum Syariah (BUS) and Unit Usaha Syariah (UUS) increased during the study period, that is 2012-2016. Almost all TPF channeled into financing, even in August 2016, Financing to Deposit Ratio (FDR) reached 91,40\%, which shows that the demand for the higher liquidity of Islamic banking. TPF decreased compared with the total financing that started at the end of 2012. Based on the Islamic banking development Report in 2012, this was due to the adjustment of TPF to the decline in interest rates and the withdrawal of funds by the Ministry of Religious Affairs Hajj of 4.2 trillion rupiah.

The total financing of Islamic bank increase every year and according to 0JK data in November 2015 the total financing of Islamic bank is 206,05 trillion rupiah, this number grow 4.09\% compared to November 2014. Even though the amount of Islamic bank total financing increase every year, is still very small compared to conventional banks. The amount of financing is only about 5,56\% of the banking total credit. This shows that the share of Islamic banking financing is still very small when compared with the share of credit of conventional commercial banks. 
Based on Bank Indonesia data in the second quarter of 2016, In general, the development of the Islamic banking industry has increased. This is reflected in the increase in the number of assets, financing, and Third Party Fund (TPF) Islamic banking respectively $0.05 \%, 2.05 \%$ and $2.45 \%$ to IDR 297,9 trillion, trillion IDR 217,9 and IDR 238,4 trillion. Although assets, financing, and TPF of Islamic banking have increased, but the performance of Islamic banking in the second quarter of 2016 decreased compared to the previous quarter as a result of the national economic recovery period and the challenges of internal improvements that still in process. This is reflected in ratios of Islamic banking performance indicators such as Gross NPF and OEOI that are increasing, while the CAR and ROA are decrease. The increase in gross NPF ratio is affected by high outstanding financing to customers in several sectors (mining, energy, transportation, housing, and trade) which decreased quality, and the new financing growth (pipeline) which has not run off significantly as well as the most of the financing nature is installment. The increasing of NPF resulting Islamic bank to establish reserves Impairment Losses bigger than before, with this condition the capital ratio, profitability and efficiency of Islamic banking have decreased

The average growth of Islamic banking assets are more than $65 \%$ in the last five years (Bank Indonesia, 2016). Until the second quarter of 2016, the proportion of assets Islamic banking to national banking assets stands at $4.8 \%$ with the proportion of assets of BUS and UUS still dominating the total Islamic banking assets (BUS + UUS + BPRS) with the percentage of $\pm 97.4 \%$.

This study analyzes the factors that affect the total financing of Islamic banking in Indonesia. Financial factors that are examined are derived from the internal side of Islamic banking. The variables used were obtained from financial ratios, especially in Bank Umum Syariah (BUS). The financial ratios consist of CAR, ROA, NPF, FDR, and OEOI, which can be obtained from the chosen bank's semiannual report to determine the significant effect on total financing in Islamic banking.

\section{LITERATURE REVIEW AND METHODS}

\subsection{Total Financing}

One of the products offered by Islamic banks is financing. Financing is generally known by the public and interesting for the customers. Financing is provided by a bank to another party to support the planned investment, either by themselves or the institution. According to the Act - Banking Law No.10 of 1998, financing is the provision of money or bills that can be equated with it, based on agreements between the Bank and another party requiring the financed party to return the money or the charges after a certain time in profit sharing. According to Antonio (2001), financing is providing facilities for the provision of funds to meet the needs of the deficit units parties. Financing is the provision of cash or the equivalent, based on agreements between the Bank and another party requiring the financed party to return the money or the charges after a certain period in profit sharing (Kasmir, 2001). Thus, total financing can be defined as the amount of facility-related costs through the provision of money or claims according to an agreement between the Bank and other parties. Funding given basically refers to the element of trust. In other words, the fulfillment of the needs given is believed to be returned by the recipient of the financing with terms and conditions agreed by both parties. 


\subsection{Capital Adequacy Ratio}

CAR is a capital ratio that shows the bank's ability to provide funds for business development and accommodating the risk of loss of funds caused by the operations of the bank. CAR indicates the extent to which the decline in bank assets can still be covered by the equity of banks available, the higher the CAR, the better the condition of a bank. Capital adequacy ratio is the ratio that shows how much all of the assets of banks that contain risks (credit investments, securities, bills to other banks) to be financed from the capital fund bank itself, in addition to obtaining funds from sources outside, such as public funds, loans (debt) and others (Dendawijaya, 2003). Based on Bank Indonesia Regulation No. 3/21/ PBI 2001 magnitude to the current CAR of at least 8\%, whereas in Indonesian Banking Architecture (API) to be the anchor bank commercial bank must have a minimum CAR of $12 \%$.

Basically, capital comes from the components of core capital and supplementary capital. Core capital consists of paid-up capital and additional reserve capital consisting of additional factors such as additional paid-in capital contributions, general reserve capital, purpose of reserve capital, current year profit - after deducting tax, current year's profit after deducting tax assessment (50\%), difference in translation of financial statements of overseas branches, and deposit of capital funds as well as reduction factors such as disagio, loss for the past year, current year, less difference in financial statement translation of overseas branches, and decrease in the value of investments in available-for-sale portfolios. Core capital is calculated by subtracting factors in the form of goodwill. Supplementary capital consists of fixed asset revaluation reserves, general reserves PPAP (maximum of $1.25 \%$ of risk-weighted assets), capital loans, subordinated loans (up to 50\% of Core Capital), and an increase in the value of investments in the portfolio available for sale a maximum of $45 \%$.

\subsection{Return on Assets}

According Riyadi (2006), ROA is defined as the profitability ratio which shows the ratio between profits and bank assets, this ratio shows the level of efficiency of asset management carried out by the bank concerned. The high profit made by the bank gets the trust of the public which allows it to increase the bank's capital more so that it has the opportunity to provide loans to a wider audience. Return on assets is a ratio that measures the level of optimization of assets owned to generate profits or profits. The minimum ROA value set by Bank Indonesia is at least $1.5 \%$. In order to seek profit and fulfill responsibility to shareholders, assess leadership performance, and increase the attractiveness of investors to invest.

\subsection{Non-Performing Financing}

NPF is the risk of financing received by the bank resulting from not nonpayment of loans or investments that are being made by the bank (Muhammad, 2005:359 in Yuliani, 2012). Non-performing financing is the ratio used to measure the ability of bank management to manage non-performing financing can be measured by the earning assets owned by the bank (Yuliani, 2012). Non-Performing Finance is the rate of return on loans granted to the bank depositors or credit crunch. The risk of bank losses due to the repayment of non-current financing will affect the revenue and profit earned by the bank (Bintang, 2013:3). According to a dictionary of Bank Indonesia, NPF is a non-performing loan consisting of loans, which are classified as substandard, doubtful, and bad loans. The term "NPL" refers to a conventional bank, while "NPF" 
refers to an Islamic bank. A Non-performing Loan is the ability of a bank to collect loans it provides until they are paid full, and Abusharba (2005) states that Non-Performing Financing is used to measure the level of financing problems faced by Islamic bank. NPF has the limit safe maximum to $4 \%$ as advised by Bank Indonesia. The higher this ratio indicating the quality of Islamic bank financing is getting worse. In other words, the smaller the NPF ratio of a bank means the more ability a bank in distributing its credit.

\subsection{Financing to Deposit Ratio}

FDR is a ratio between the number of bank loans to the funds received by the bank. FDR is determined by the ratio between the number of loans granted by public funds collected which includes demand deposits, savings deposits (deposits), and savings. FDR describes the bank's ability to repay depositors withdrawal of funds committed by relying on loans as a source of liquidity. The larger the loan, the earned income rises, revenue rises automatically because income will also increase. FDR is the ability of the bank to repay bank depositor funds by relying on financing as a source of liquidity. The higher the FDR, the higher the funds are channeled into TPF. Bank revenues will increase and FDR will be a positive influence on ROA. The standard of Bank Indonesia (BI) to FDR ratio is 78\% - 100\%. If FDR is less than 78\% (eg 60\%), then the FDR of $60 \%$ means $40 \%$ of all funds raised are not distributed to those in need, so the bank does not function properly (Anggraini, 2014).

\subsection{Operating Expense to Operating Income}

The ratio of operating expenses to operating income calculated using the ratio of operating expenses to operating income or in Indonesia is often referred to as BOPO. Given the bank's main activity is collecting and distributing funds, the interest costs and bank operating income is dominated by interest expense and interest income. Dendawijaya (2003) states that the smaller this ratio means more efficient operational costs incurred by the bank concerned that a bank error is getting smaller. The ratio of Operating Expenses to Operating Income (OEOI) is often called the efficiency ratio is used to measure the ability of bank management in controlling the operating expenses to income ratio. This means more efficient operational costs incurred by the bank concerned. OEOI has a significant effect on the total distribution of credit. According to Bank Indonesia regulation, the ideal value of the OEOI ratio that banks should have to show a good level of bank efficiency is between $50 \%-75 \%$. If the ratio is above $90 \%$ and/or nearly $100 \%$, it shows that the performance of a bank has a very low level of efficiency.

\subsection{Theoretical Framework}

Theoretical framework is very important in the scientific literature because in the theoretical framework will be published theories that are relevant in explaining the problem that is being investigated. Later this framework is used as a theoretical basis or rationale in the research conducted. Because a researcher needs to develop a theoretical framework which includes the main points of thinking that will describe the terms of which a problem is highlighted. 


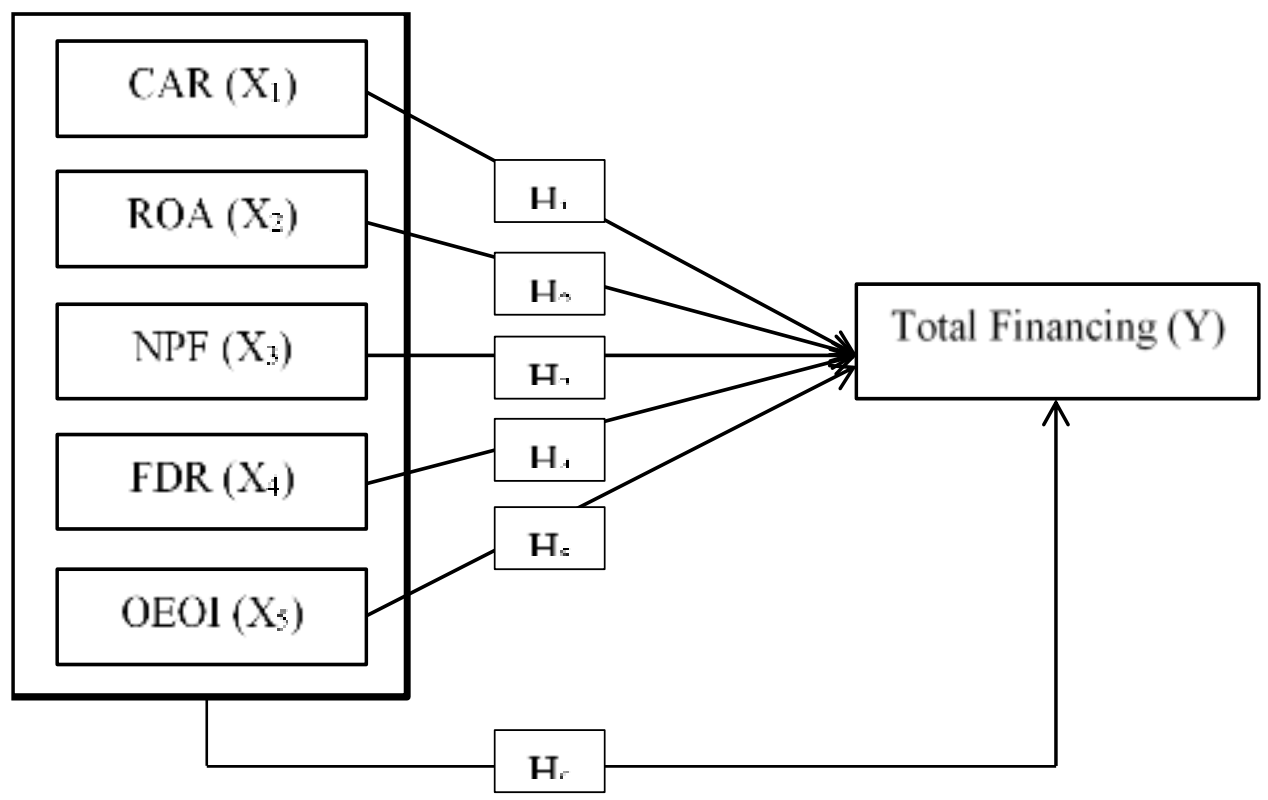

Figure 1. Theoretical Framework

According to the literature review and previous research, the researcher had arranged the hypothesis and then illustrated it in the theoretical framework above. This research consisted of five independent variables consisting of CAR, ROA, NPF, FDR, and OEOI, and one dependent variable which is Total Financing.

\subsection{Hypotheses}

This research has six hypotheses to be tested. Based on the statement of problem, and theoretical framework above the hypotheses of this research are described as follow:

Hypothesis 1: Capital Adequacy Ratio has a significant effect on total financing in Islamic Bank.

Hypothesis 2: Return On Assets has a significant effect on Total Financing in Islamic Bank.

Hypothesis 3: Non-Performing Financing has a significant effect on Total Financing in Islamic Bank.

Hypothesis 4: Financing to Deposit Ratio has a significant effect on Total Financing in Islamic Bank.

Hypothesis 5: Operating Expense Operating Income has a significant effect on Total Financing in Islamic Bank.

Hypothesis 6: Capital Adequacy Ratio, Return on Asset, Non-Performing Financing, Financing to Deposit Ratio, Operating Expense Operating Income has simultaneous significant effect on Total Financing in Islamic Bank.

\subsection{Research Method}

In doing research, there are two types of analyzing methods, which are quantitative analysis and qualitative analysis. Quantitative research is a systematic scientific investigation of data and its variables. It shows the cause and effect relationship of independent and dependent variable, the measurement should be objective, quantitative, and statistically valid. Quantitative research explains the 
phenomenon through the collection of numerical data which is carried out by mathematical-based analysis, especially statistics. The uniqueness of this research is in the form of numerical data collection. The specificity of quantitative research is collecting numerical data. In contrast, qualitative methods are more subjective because they use different methods of gathering information such as interviews, questionnaires, and focus group discussions. Qualitative research methods tend to explain and describe meanings, concepts, definitions, characteristics, metaphors, and symbols through observation.

\subsection{Population and Sample}

Population is the generalization area that consisted of objects or subjects with certain qualities or characteristics which are determined by the researcher to be studied and concluded (Sugiyono, 2009). The populations in this study are the Bank Umum Syariah (BUS) in Indonesia. Sampling is the some components that represent the total population to reach an inference (Cooper \& Schindler, 2011). The sample was taken from 10 of Islamic banks in Indonesia. These banks are: Bank Muamalat Indonesia, Bank Victoria Syariah, Bank BRI Syariah, Bank Jabar Banten Syariah, Bank BNI Syariah, Bank Syariah Mandiri, Bank Mega Syariah, Bank Panin Syariah, Bank Syariah Bukopin, and Bank BCA Syariah. These banks were selected because they all have the semiannual data required on six variables on June \& December 2012 to 2016.

\subsection{Multiple Linear Regression}

The method used in this research is multiple regression analysis. Multiple regression analysis was utilized to foresee substantial factors (dependent variable) utilizing information from at least two free factors (independent variable) were already known to the magnitude (Santoso, 2010). This quantitative data analysis begins with collecting data and then processed using SPSS. SPSS is a computer application that can analyze data and perform statistical calculations to test normality, heteroscedasticity, autocorrelation, multicollinearity, and multiple regression. The data used in this research is time-series data with the semiannual period. Multiple linear regression equation is as follows:

$$
Y=\beta_{0}+\beta_{1} X_{1}+\beta_{2} X_{2}+\beta_{3} X_{3}+\beta_{4} X_{4}+\beta_{5} X_{5}+\varepsilon
$$

$\mathrm{Y}$ is total financing, $\beta$ o is constant, $\mathrm{X} 1$ is capital adequacy ratio, $\mathrm{X} 2$ is return on asset, $\mathrm{X} 3$ is the non-performing financing, $\mathrm{X} 4$ is financing to deposit ratio, X5 is operating expense operating income, $\beta_{1} \ldots . . \beta_{5}$ are regression coefficient and $\varepsilon$ is an error. The regression coefficient value in this study plays a very important role as a basis of analysis. If the $\beta$ coefficient value is positive $(+)$, it can be concluded that there is a direct effect between the independent variable and the dependent variable. An increment of the independent variable score will give a result in raising the value of the dependent variable. Vice versa, when the $\beta$ coefficient value is negative (-), it shows the negative effect where the increment of the independent variable will result in to decrease in the dependent variable value. 


\section{RESULT AND DISCUSSION}

\subsection{Descriptive Statistic}

The descriptive analysis shows the minimum, maximum, and mean values for all variables. The endogenous or independent variables are Capital Adequacy Ratio , Return on Assets, Non-Performing Financing, Financing to Deposit Ratio (FDR), and Operating Expense Operating Income (OEOI) while the dependent variable or the extraneous variable is total financing. The data is taken in form of panel data from 10 Islamic banks in Indonesia. These banks are: Bank Muamalat Indonesia, Bank Victoria Syariah, Bank BRI Syariah, Bank Jabar Banten Syariah, Bank BNI Syariah, Bank Syariah Mandiri, Bank Mega Syariah, Bank Panin Syariah, Bank Syariah Bukopin, and Bank BCA Syariah. These banks were selected because they all have the data required on six variables on June \& December 2012 to 2016. All data are secondary data obtained from the OJK (Otoritas Jasa Keuangan) at www.ojk.go.id.

Table 1. Descriptive Statistics

\begin{tabular}{|c|c|c|c|c|c|}
\hline & $\mathrm{N}$ & Minimum & Maximum & Mean & Std. Deviation \\
\hline CAR & 90 & 10.74 & 45.65 & 18.2888 & 6.90132 \\
ROA & 90 & -7.46 & 4.13 & .8754 & 1.36358 \\
NPF & 90 & .01 & 13.54 & 2.8074 & 2.04641 \\
FDR & 90 & .00 & 140.48 & 89.0526 & 24.36908 \\
OEOI & 90 & 50.76 & 177.90 & 90.9670 & 14.93517 \\
Valid N (listwise) & 90 & & & & \\
\hline
\end{tabular}
Source: SPSS 22

The CAR has a minimum value of 10.74 (Bank Syariah Bukopin in June 2014); a maximum value of 45.65 (Bank Panin Syariah in June 2012); and a mean value of 18.288. The ROA variable has a minimum value of -7.46 (Bank Victoria Syariah in June 2016); a maximum value of 4.13 (Bank Mega Syariah in June 2012); and a mean value of 0.8754. The NPF variable has a minimum value of 0.01 (Bank BCA Syariah in June 2013); maximum value 13.54 (Bank Jabar Banten Syariah in June 2016); and mean value of 2.8074. The FDR variable has a minimum value of 0.00 (Bank Victoria Syariah in December 2012); maximum value 140.48 (Bank Panin Syariah in June 2014); and mean value of 89.0526. While the OEOI variable has a minimum value of 50.76 (Bank Panin Syariah in December 2012); a minimum value of 177.90 (Bank Victoria Syariah in June 2016); and a mean value of 90.9670 .

\subsection{Multiple Linear Regression}

The multiple linear regression equation can be formulated from the beta in unstandardized coefficients. The standardized coefficient express all coefficients in terms of the same units and it is good to compare the size of the influences of different independent variables. 
Table 2. Multiple Linear Regression Analysis

\begin{tabular}{|c|c|c|c|c|c|}
\hline \multirow[b]{2}{*}{ Model } & \multicolumn{2}{|c|}{ Unstandardized Coefficients } & \multirow{2}{*}{$\begin{array}{c}\text { Standardized } \\
\text { Coefficients }\end{array}$} & \multirow[b]{2}{*}{$\mathrm{t}$} & \multirow[b]{2}{*}{ Sig. } \\
\hline & $\mathrm{B}$ & Std. Error & & & \\
\hline $\begin{array}{ll}1 & \text { Constant } \\
& \text { ) }\end{array}$ & 33024465.265 & 14032029.424 & & 2.354 & .021 \\
\hline CAR & -328535.612 & 144850.883 & -.245 & -2.268 & .026 \\
\hline ROA & -1087334.199 & 1406797.418 & -.160 & -.773 & .442 \\
\hline NPF & 1773074.438 & 533001.326 & .392 & 3.327 & .001 \\
\hline FDR & -894.759 & 35875.526 & -.002 & -.025 & .980 \\
\hline OEOI & -270263.351 & 124631.711 & -.436 & -2.168 & .033 \\
\hline
\end{tabular}

Source: SPSS 22

Based on table 2 the equation can be written as follows:

$$
\begin{gathered}
\mathrm{Y}=33024465.27-328535.612{ }^{*} \mathrm{CAR}+1773074.438 * \mathrm{NPF}-270263.351 \\
{ }^{\star} \mathrm{OEOI}
\end{gathered}
$$

The constant value of this regression model is 33024465.265. CAR variable has a coefficient value of -328535.612 , ROA variable has a coefficient value of -087334.199; NPF variable has a coefficient value of 1773074.438; FDR variable has a coefficient value of -894.759; and OEOI variable has a coefficient value of -270263.351. Independent variables CAR, ROA, FDR \& OEOI has negative coefficient meaning that there are negative relationship on these four variables toward Total financing. Only NPF shows a positive relationship with Total Financing. Sig value for the independent variables show that $\mathrm{CAR}=0.026(<0.05) ; \mathrm{ROA}=0.442(>0.05) ; \mathrm{NPF}=0.001(<0.05)$; $\mathrm{FDR}=0.98(>0.05)$; and OEOI $=0.033(<0.05)$. It appears that only CAR, NPF, and OEOI have sig value $<0.05$ and therefore these three variables are said to have a significant effect on Total Financing.

\subsection{Interpretation of Results}

\section{a. The Influence of Capital Adequacy Ratio towards Total Financing in Bank Umum Syariah}

The hypothesis testing revealed a sig value of $.026(<0.05)$. Therefore the hypothesis is accepted meaning that the capital adequacy ratio has a significant effect on total financing in Islamic banks. The capital adequacy ratio is a measure of a bank's capital, which is is expressed as a percentage of a bank's risk-weighted credit exposures. Capital adequacy ratio is an international standard that measures a bank's risk of insolvency from excessive losses. Currently, the minimum acceptable ratio is $8 \%$. Maintaining an acceptable car protect depositors and promote the stability and efficiency of the financial system as a whole. Total financing or the total amount of facility-expenses related through the provision of money or bills on Islamic banking financing is still very small when compared with the share of credit of conventional commercial banks. The results of this study indicate that an increase or decrease in CAR during the study period will significantly affect the total financing. The lower the CAR, the greater the amount of loans distributed. The average Islamic bank capital adequacy ratio is high which is $18.2888 \%$. The recovery 
of the economy and banking industry gradually has driven optimization utility source which is financial resources (capital) through credit. The increase of total financing of Bank Umum Syariah is in line with the decrease of CAR. The results of this research consistent with the results of previous research conducted by Lestari (2015), which states that the CAR has a significant negative effect on bank credit.

\section{b. The Influence of Return on Asset towards Total Financing in Bank Umum Syariah}

The return on assets shows the percentage of how profitable a company's assets are in generating revenue. Return on assets indicates the capital intensity of the company. Hypothesis 2 said that return on assets has a significant effect on total financing in Islamic banks. The sig value for this is 0.442 (which is $>0.05$ ) and therefore this hypothesis is rejected meaning that return on the asset does not affect total financing in an Islamic bank. This shows that the higher the level of profit in the previous year did not affect the total financing in the current year. This study consistent with the results of previous research performed by Febrianto (2013) which states that the ROA does not affect lending.

\section{c. The Influence of Non-Performing Financing towards Total Financing in Bank Umum Syariah}

The sig value for this hypothesis is $0.001(<0.05)$. Meaning that this hypothesis is accepted. Non-performing financing is the sum of borrowed money upon which the debtor has not made his scheduled payments for at least 90 days. Nonperforming finance can reasonably be expected to enter default. The results of this study differ from previous studies. NPL has a negative effect but not significant. In the study result, the NPL has a significant negative effect against lending to MSMEs. The results is different because it can be caused by the amount of NPF on each research. The positive research may be due to the low NPF of Islamic banking. Besides, according to Triasdini (2010), when the financing of the bank increase there is a possibility that the NPF will increase. NPF increased in line with the total financing. Therefore, bank management considers that increase of NPF is normal if it is still in good criteria.

\section{d. The Influence of Financing to Deposit Ratio towards Total Financing in Bank} Umum Syariah

The sig value for this hypothesis is 0.98 . Therefore the hypothesis is rejected meaning that the financing to deposit ratio has no effect on total financing in Islamic Bank. This research has a different result from the previous research conducted by Nugroho (2014), which stated that FDR has a significant positive effect on total financing in Islamic banks.

\section{e. The Influence of Operating Expense Operating Income towards Total Financing in Bank Umum Syariah}

The sig value for this hypothesis is 0.033 . Therefore this hypothesis is accepted, which means that Operating Expense Operating Income has a significant effect on total financing in Islamic Bank. OEOI is the ratio of operating expenses to operating income which is often referred to as BOPO or the efficiency ratio is used to measure the ability of bank management in controlling operating expenses to income ratio. Given the bank's main activity is collecting and distributing funds, the interest costs 
and bank operating income is dominated by interest expense and interest income. The smaller this ratio means more efficient operational costs incurred by the bank concerned that a bank error is getting smaller. Better OEOI meaning that the bank will have more funding for financing. The result of the research shows that the average OEOI ratio is $90.9670 \%$ which is not good criteria. The lower OEOI ratio of the bank means more efficiency in controlling its operating costs, with good cost efficiency the profit of the will be even greater. This research has different results from the previous research conducted by Nugraha (2014), which stated that OEOI has no significant negative effect on total financing in Islamic banks.

f. Capital Adequacy Ratio, Return on Asset, Non-Performing Financing, Financing to Deposit Ratio, Operating Expense Operating Income has Simultaneous Significant Effect on Total Financing in Bank Umum Syariah

The sig value for this hypothesis is $.000 \mathrm{~b}(<0.05)$. Therefore the hypothesis is accepted. Based on the analysis, there are four hypotheses accepted $\left(\mathrm{H}_{1}, \mathrm{H}_{3}, \mathrm{H}_{5}\right.$, and $\left.\mathrm{H}_{6}\right)$ and 2 hypotheses rejected $\left(\mathrm{H}_{2}\right.$ and $\left.\mathrm{H}_{4}\right)$. Adjusted $\mathrm{R}$ Square value is 0.239 or $23,9 \%$. This value shows that the percentage of the contribution of independent variables on total financing is $23.9 \%$. The remaining percentages are due to other variables excluded in this model.

\section{CONCLUSIONS}

This research aims to provide descriptive statistics of CAR, ROA, NPF, FDR, OEOI, and Total Financing of 10 Islamic banks in Indonesia based on panel data $2010-2016$. This research also analyzes the partial and simultaneous effect of CAR, ROA, NPF, FDR, and OEOI on the Total Financing of 10 Islamic banks in Indonesia.

Based on data analysis it is shown as following:

1. Capital adequacy ratio has a significant negative impact on total financing of Bank umum syariah. Based on the result of regression, the CAR variable has a coefficient value of -328535.612 , meaning that if CAR increases 1 point the total financing will decrease 328535.612 points. Based on hypothesis testing, the Sig value for the independent variables shows that $\mathrm{CAR}=0.026(<0.05)$. Therefore, the hypothesis is accepted because the significant value is less than 0.05 meaning that Capital Adequacy Ratio has a significant effect on total financing in total financing of BUS.

2. Return on asset has no significant impact on total financing of Bank umum syariah. ROA variable has a coefficient value of -087334.19. Based on hypothesis testing, the sig value for $\mathrm{ROA}=0.442(>0.05)$. Therefore, this hypothesis is rejected because the significant value is more than 0.05 meaning that the coefficient value is not applicable because the return on asset has no effect on total financing in total financing of BUS.

3. Non-performing financing has a significant positive impact on total financing of Bank umum syariah. NPF variable has a coefficient value of 1773074.438 , meaning that if CAR increases 1 point the total financing will increase 1773074.438 points. Based on hypothesis testing, the sig value for NPF $=0.001(<0.05)$ meaning that this hypothesis is accepted that NPF has a significant effect on total financing in Islamic Bank.

4. Financing to deposit ratio has no significant impact towards total financing of Bank umum syariah. FDR variable has a coefficient value of -894.759. Based on 
hypothesis testing, the sig value for FDR $=0.98(>0.05)$. Therefore, this hypothesis is rejected because the significant value is more than 0.05 meaning that the coefficient value is not applicable because FDR has no effect on total financing in total financing of BUS.

5. Operating expense operating income ratio has a significant negative impact on total financing of Bank umum syariah. OEOI variable has a coefficient value of 270263.35, meaning that if OEOI increases 1 point the total financing will decrease 270263.35 points. Based on hypothesis testing, the sig value for OEOI $=0.033$ $(<0.05)$. Therefore this hypothesis is accepted, which means that Operating Expense Operating Income has a significant effect on total financing of BUS.

6. Capital Adequacy Ratio, Return on Asset, Non-Performing Financing, Financing to Deposit Ratio, and Operating Expense Operating Income have simultaneous significant effect towards total financing of Bank umum syariah. All Independent variables CAR, ROA, NPF, FDR \& OEOI have sig value of .000b $(<0.05)$. Therefore the hypothesis is accepted meaning that All Independent variables CAR, ROA, NPF, FDR \& OEOI have a simultaneous significant effect on total financing of BUS. 


\section{REFERENCES}

Anggraini, Mei (2014). Analisis Pengaruh Financing to Deposits Ratio (Fdr) dan Loan To Assets Ratio (Lar) Terhadap Profitabilitas Perbankan Syariah Di Indonesia (Studi Kasus Pada Bank Umum Syariah Periode 2009-2013). Universitas Muhammadiyah Surakarta

Antonio, Muhammad Syafi'i. (2001), Bank Syariah Dari Teori ke Praktik. Gema Insani Press. Jakarta

Bank Indonesia. (2016). Sekilas Perbankan Syariah Di Indonesia. From http://www.bi.go.id/id/perbankan/syariah/Contents/Default.aspx

Budisantoso, T dan Triandaru, S. (2006), Bank dan Lembaga Keuangan Lain, Salemba mpat: Jakarta.

Cooper, D.dan Schindler, P. S. (2011), Marketing Research., McGraw Hill

Dendawijaya, Lukman. (2003), Manajemen Perbankan. Jakarta : Ghalia Indonesia

Kasmir (2001), Bank dan Lembaga Kuangan Lainnya. Edisi Keenam, Jakarta : PT. Grafindo Persada

Febrianto, (2013). Analisis Pengaruh Kepemilikan Institusional, Komite Audit, Komisaris Independen, dan Audit Report Lag terhadap Integritas Laporan Keuangan (Studi Empiris pada Perusahaan Manufaktur yang Terdaftar di Bursa Efek Indonesia pada Tahun 20112012)

Lestari , Mulikhah (2015), Pengaruh Religiusitas, Produk Bank, Kepercayaan, Pengetahuan, Dan Pelayanan Terhadap Preferensi Menabung Pada Perbankan Syariah (Studi Kasus Pada Mahasiswa Fakultas Ekonomi Dan Bisnis Universitas Brawijaya Malang). Malang. Jurnal Ekonomi Kan Keuangan. http://jimfeb.ub.ac.id/index.php/jimfeb/article/viewFile/1598/1464

Nugraha, Ardi (2014). Pengaruh Pengumuman Right Issue Terhadap Tingkat Keuntungan dan Likuiditas Saham di Bursa Efek Indonesia, Jurnal Manajemen dan Bisnis Sriwijaya (JMBS), 2013

Riyadi. Slamet (2006), Banking Asset and Liability Management. Jakarta: Fakultas Ekonomi Universitas Indonesia

Santoso, S. (2010), Mastering SPSS 18. Jakarta: PT Elex Media Komputindo

Sugiyono. (2009). Statistika untuk Penelitian, Cetakan Keempat, Bandung: Alfabeta

Sugiyono (2009), Metode Penelitian Kuantitatif, Kualitatif dan R\&D, Bandung : Alfabeta

Triasdini, Himaniar (2010), Pengaruh CAR, NPL, dan ROA terhadap Penyaluran Kredit Modal Kerja. Skripsi. Dipublikasikan. Semarang: Universitas Diponegoro

Yuliani, Elsa. (2012). Pengaruh Non Performing Financing Dan Dana Pihak Ketiga Return On Assets (Studi Kasus Pada PT. Bank Rakyat Indonesia Syariah 2008-2012). Universitas Komputer Indonesia 